\title{
American Pentecostalism, the 8:46 Moment, and the Covid-19 Pandemic
}

As we, the editors, mapped out this issue, this was not the editorial we planned to write. That is because this issue of Pneuma is being published in the midst of two major social crises, largely unanticipated at the beginning of 2020, in which Pentecostal communities, along with the rest of the world, have found themselves: the racial awakening sweeping the United States of America and the global covid-19 pandemic.

These two events have exposed the fragility of most nations' institutions for social justice, their antiquated moral fabrics, pressings problems of aging and ailing healthcare systems, dangerous levels of social and economic inequalities, and sometimes just the simple lack of moral concern for one's neighbor. In the United States, these two events have unequivocally demonstrated the unacceptable level of suffering, discrimination, and vulnerability to death of minorities, especially African Americans.

As an academic journal deeply rooted in the Christian tradition, anchored by love for all God's children, driven by a vision of equality of all races and peoples, and committed to human flourishing for all, we would like to remind the United States and all our readers that black lives matter. When we value black lives, which for centuries in America have not been considered important, then all lives of God's children will truly matter.

American Pentecostalism, right from its inception, has struggled with the social-ethical implications of the gift of the fire of the Holy Spirit that is the baptism of the Holy Spirit. William Seymour, the leader of the Azuza Street revival - a black man well-acquainted with racism and accustomed to being treated as a second-class citizen in his own country by the majority white population-declared that the most important indication of any life transformed by God's Spirit is the radical commitment to a racially inclusive community. Pentecost, he declared, "brings us all into one common family." America is yet to live up to this simple vision of Seymour. ${ }^{1}$

1 The Apostolic Faith (Los Angeles), II:13, 3 (May 1908). 
The senseless killing of a black man George Floyd in the hands of a white police officer kneeling on his neck for eight minutes and forty-six seconds on May 25, 2020 in Minneapolis is a sad reminder that the United States and its predominate majority of Christians are far from realizing the ideals of Pentecost and life-in-the Spirit that so moved Seymour and others at Azuza Street over a century ago. Floyd, who had been involved with a black church in Houston, Texas until moving to Minnesota in 2018, had his slow, agonizing, and cruel death streamed live on video for the world to watch. Yet it kindled the fire of racial awakening that is now sweeping across the United States and the world. His death came in the wake Ahmaud Arbery's killing by three white men in Georgia while out on a jog, and Breonna Taylor's in her sleep in Louisville in a horribly botched raid by police officers where the wrong home was raided. The African-American community and many who care deeply about the community's plight could not take it any longer. The killings of the three African Americans caused the long-running demonic triumvirate of racism, intolerance, and devaluation and de-mattering of black lives to crystallize in an unprecedented way for many Americans, both black and white.

Consequently, there has been an awakening to the broader consciousness of the 40o-year-old history of racism and racial division in America, and the world has been further awakened to the continued legacy of racial oppression. At the time of the writing of this essay, protests and riots have spread throughout over a hundred locations in the United States. The path of our future has been altered, and we hope for Pentecostal scholarship that will rise to the occasion with this historical moment. We hope Christians all over the world will seize this "8:46 moment" to commit themselves and their resources toward racial equality. It took the brutal knee pressing down on Floyd's neck for 8:46 minutes to snuff out his precious life, even as he desperately cried "I can't breathe." Pneuma, the breath of life, the wind of livingness, the Spirit, the breath of God in Floyd's nostrils was forcefully expelled from his body. Pentecostals who celebrate the Pneuma of God in the world and who claim to be moved and guided by the Spirit of God cannot and should not support any social system that recklessly devalues the life force in and wellbeing of any of God's children.

While our constituencies at Pneuma are global, the origination of this journal with North American Pentecostals, whose histories are tied to this racialized history, and the significant involvement of Pentecostal churches in America's race relations makes this crisis especially notable. The history of American Pentecostalism is, of course, mixed and troubled as it has been hopeful and beautiful, just as members of the Society and Pneuma itself have been leading sources accounting for this history. But this moment demands unalloyed commitment to love and justice of our African-American brothers and sisters. 
The "8:46 moment" unambiguously calls for American Pentecostals to jettison racism and embrace justice and dignity for all God's children. Anything less is incompatible with the life of the Spirit.

This all comes amidst another major crisis. At the time of the composition of this editorial, in mid-June 2020, the novel coronavirus has infected over 8 million persons worldwide with over 450,00o dead, and these numbers just represent the officially reported cases from the first wave of the virus. Medical experts and governments hope for a vaccine to come to humanity's rescue by the end of 2020 or early 2021. Sizeable Pentecostal communities, from London to New York City to São Paulo, are located in some of the hardest hit locations.

With an unprecedented challenge before the Society for Pentecostal Studies, in its second emergency meeting (a first emergency meeting was held on March 5,2020 ) on this issue, and with inconclusive data at the time accounting for the initial spread of the virus occurring, on March 10 the Executive Committee made what seemed at that time to be a very difficult decision to cancel the Society's Annual Meeting scheduled for March 19-21 at Vanguard University in Costa Mesa, California, barely a mere week-and-a-half prior to this annual beloved event.

We on the Executive Committee (Pneuma editors serve as ex-oficio members) did not fully realize then that the Society was early in a cascade of cancellations and shutdowns which would occur throughout March-April 2020. In the coming weeks, Pentecostal colleges and universities, along with others throughout higher education, would move to virtual classrooms through the end of their spring terms. The world and national economies have faced significant economic challenges in these times, with the unemployed, businesses, and even religious institutions sustained with government aid, with the hope that these will be merely temporary measures. The move to virtual church gatherings across the world has significantly changed how Christian communities are functioning in ways hardly imagined beforehand. No one can be sure how long and how difficult the road will be, and yet the innovations and creative ways in which Christian communities have dealt with unforeseen circumstances will likely lead to unforeseen effects on the future of Christianity. Therefore, as the editors, we put out an invitation to respond to this global pandemic in the form of submissions to this journal through an e-mail from the Society's Executive Director, Adrian Hinkle, to our membership on April 13. The path of our future has been altered, it seems, and we invite our scholars to put forth works considering the intersection of Pentecostalism and the CoviD-19 pandemic.

These two crises have been the strong waters in which we have swum in recent months. Yet, other work in Pentecostal studies has come to fruition. This 
issue includes four articles and a report on the third phase of the International Reformed-Pentecostal Dialogue before our book reviews.

In the year 2000, and on his way to becoming one of the more influential North American Christian philosophers, James K.A. Smith provided the initiative for beginning the Philosophy Interest Group of sPS. He did so with the encouragement of some key figures in Pentecostal studies, including especially that of Amos Yong. In 2003, Smith wrote an influential article entitled "Advice to Pentecostal Philosophers," which appeared in an issue of the Journal of Pentecostal Theology. ${ }^{2}$ Drawing on the Reformed Christian philosopher Alvin Plantinga's noted "Advice to Christian Philosophers," which called on Christian philosophers to draw on their own Christian affirmations about reality in Christian philosophical projects, ${ }^{3}$ Smith called on Pentecostal philosophers to do philosophy from their own Pentecostal understanding of the world, embedding theological and faith assumptions into the task of philosophy. ${ }^{4}$

The Philosophy Interest Group, since led by Jack Wisemore (2002-2005), Doug Olena (2005-2008), one of your editors-L. William (Bill) Oliverio, Jr. (2008-2014), and then Doug Olena again (2014-Present) has engaged in significant dialogues regarding the relationship between philosophical work and Pentecostal studies. Significant philosophical voices (several of whom overlap disciplinary domains) including Harvey Cox, D. Stephen Long, James K.A. Smith, Charles Taylor, Merold Westphal, and Amos Yong, among others who deserve to but cannot all be listed here, have participated in sessions sponsored by the Group since, and your two editors of Pneuma, respectively, have primarily identified with the it in their SPS membership and participation.

This issue features a philosophical dialogue set within this context, between J. Aaron Simmons, a Pentecostal drummer at his local Assemblies of God church in South Carolina, where he is also Professor of Philosophy at Furman University and the President of the Søren Kierkegaard Society, and Yoon Shin. Simmons provides a new call to form new kinds of Pentecostal philosophies "... not ... reducible to a kind of pentecostal theology," as he argues that pentecostal philosophy ought to appropriate itself to theological and philosophical audiences. Arguing for a Thomistic-like turn, he contends for a methodologically diverse sets of approaches for the future of pentecostal philosophy.

2 James K.A. Smith, "Advice to Pentecostal Philosophers," Journal of Pentecostal Theology 11:2 (October 2003): 235-247.

3 Alvin Plantinga, "Advice to Christian Philosophers," Faith and Philosophy:Journal of the Society of Christian Philosophers 1:3 (July 1984): 253-271.

4 See also James K.A. Smith, Thinking in Tongues: Pentecostal Contributions to Christian Philosophy, Pentecostal Manifestos (Grand Rapids, MI: Eerdmans, 2010). 
Recounting some of the major developments in approaches to pentecostal philosophy, he offers testimony from his own pentecostal identity, while he finds certain North American socio-cultural-political identities as the problematic source of a bit of opposition to the development of much of pentecostal philosophical work. In the end, Simmons proposes, as he has done elsewhere, a "mashup" approach to philosophy, "whereby we draw on whatever philosophical resources are relevant to the questions at hand, pentecostal philosophy should display a pluralist and dynamic engagement with both the history of philosophy and its contemporary expressions. In this way, pentecostal philosophers ought mutually to appropriate the logical rigor and conceptual precision of analytic philosophy as well as the hermeneutic awareness and focus on embodied material existence occurring in continental philosophy." Simmons also recommends that pentecostal philosophy also take a cue from pentecostal worship and not be boring. In broad brush strokes, Simmons might be understood as offering a Thomistic-like turn for pentecostal philosophy in response to the Augustinian turn of Smith and others. One of those in the guild who has leaned towards the more Augustinian approach is Yoon Shin, an emerging Pentecostal philosophical theologian who teaches at Southeastern University in Florida. He provides an appreciative critique of Simmons' turn away from the nexus of Augustine-Plantinga-Smith, providing a rejoinder on behalf of a prominent stream of Christian thought. This dialogue is representative of a growing conversation concerning the intersection of Pentecostalism and philosophy, though not exhaustive in pointing out current trends.

Another ongoing philosophical dialogue has been the hermeneutical discussions and debates which have been, more or less, ongoing since the Fall 1993 issue of Pneuma, which initiated a debate on multiple levels of philosophical, theological, and biblical hermeneutics that has been a continual focus of contemporary Pentecostal studies since. Two of those who have contributed to this focus have been Scott Ellington and Jack Poirier. Our third article in this issue provides the second rejoinder in the issue, this time from Poirier to Ellington, as Poirier clarifies his arguments in light of a critique from Ellington, and then further argues for his intentionalist hermeneutic of Scripture. Our purpose in publishing the continuation of this debate is simply that quality reasoning on these issues needs to be properly aired, even when the debates within our guild can become at least somewhat contentious. Ellington and Poirier are both key contributors, and both of their work is appreciated by us as editors, no matter what we personally affirm or disaffirm on these matters.

The fourth article in this issue turns to South America, in a research article on Chilean Pentecostalism from two anthropologists, Miguel Ángel Mansilla and Carlos Piñones Rivera, and a historian, Marcela Tapia Ladino, as they 
analyze the categories used to understand pentecostal identities in relation to migration to the Tarapacá region of Chile. Identities are negotiated and overlap through patterns of migration in a "complex, contradictory and conflictive process because it is combined with other such variables as indigenous and gender variables as well as those linked to work and ecclesiastic spaces." The authors produce new research that offers new data and reconsiders Chilean Pentecostalism in relation to these emerging dynamics.

The final item before our book reviews in this volume is a summary note from Jean-Daniel Plüss, the secretary for the Pentecostal dialogue team, on the completed third phase of the Reformed-Pentecostal Dialogue. Since David du Plessis pioneered Pentecostal participation in bilateral ecumenical dialogues, representatives of Pentecostal churches and movements have partnered with their counterparts from other Christian traditions in producing a significant set of documents in Christian bilateral relations which has left a legacy for generations to come, as these have distilled the theological understandings, ecclesial practices, and spiritualities of major Christian traditions, side-by-side, providing model documents for intrareligious dialogue. Plüss provides us here with helpful summation of this last round of dialogue, and we, as the editors, invite responses to the dialogue in the form of article submissions for coming issues of this journal. A link address to the full dialogue document is provided at the end of this note.

Even amidst this largely unanticipated season, in which underlying potentialities have broken out into the open in the late modern world, scholarship on Pentecostalism continues to grow and flourish, providing needed reflection on the many unanticipated pentecostal movements which have emerged over the past twelve decades. We look forward to the new ways in which our guild will respond to the current crises so that, even amidst tragedy and difficulties, the work of the Spirit and the many tongues of Pentecost might be accounted for in the new things that will now emerge.

Nimi Wariboko and Bill Oliverio 